\title{
AERATED CONCRETE AS AN ENERGY-EFFICIENT MATERIAL FOR WALLS
}

\author{
${ }^{1}$ Zavoloka M.V., Ph.D., Professor, \\ mvzavoloka@ukr.net, ORCID: 0000-0002-2080-1230 \\ ${ }^{1}$ Zavoloka Yu.M., Engineer-technologist, \\ yurii.m.zavoloka@gmail.com, ORCID: 0000-0003-0033-6025 \\ ${ }^{1}$ I.I. Grynyova, Ph.D., \\ irene.grinyova@gmail.com, ORCID: 0000-0001-7637-6029 \\ ${ }^{1}$ Zavoloka Yu.V., Associate Professor, \\ yurii.zavoloka1@gmail.com, ORCID: 0000-0002-2741-0515 \\ ${ }^{1}$ Odessa State Academy of Civil Engineering and Architecture \\ 4, Didrikhsona str., Odesa, 65029, Ukraine
}

\begin{abstract}
In the context of tightening the thermo-technical requirements for building envelopes, the benefits and advantages of energy-efficient wall material of autoclaved aerated concrete and aerated concrete products are shown.

Domestic and foreign researches in the field of rational use of autoclaved aerated concrete for external walls in modern construction of energy-efficient buildings and optimization of structural solutions of aerated concrete walls are generalized. The most important thermos-physical characteristic for assessing the thermal resistance of external walls made of aerated concrete is the value of the thermal conductivity coefficient. The moisture content of aerated concrete has a significant effect on thermal conductivity, the release moisture is several times higher than the calculated moisture content stipulated by the standards for construction heat engineering and operating conditions. In the initial stages of construction, the moisture content of aerated concrete exceeds the moisture content established in the normative documentation by operating conditions, which requires recalculation of the thermal resistance of the walls of buildings taking into account the real moisture content of aerated concrete used during construction. A detailed explanation of the dependence of the heat flow through the enclosing structure on its resistance to heat transfer, established in the form of a hyperbola, is given, and the dependence of the difference in thermal conductivity on the moisture content of aerated concrete blocks is presented. When analyzing the effect of moisture on the thermal conductivity of aerated concrete, was used the characteristic deviation $\pm \Delta \lambda$ of thermal conductivity of aerated concrete in a wet state from the thermal conductivity of concrete in a dry state was used. Based on the results of the experiment carried out at OSACEA, the main conclusions and recommendations for determining the coefficient of thermal conductivity of aerated concrete in dry and wet conditions are given. Some aspects of energy saving in construction practice are presented, based on materials prepared by Doctor of Technical Sciences, prof. Gagarin V.G. The need to improve specific energy-saving measures is shown, which should be economically viable and not reduce the durability of construction objects. Generalized conclusions and recommendations are given.

Keywords: energy-efficient buildings buildings, rational use, autoclaved aerated concrete, external walls, wall optimization, aspects, thermal conductivity coefficient, humidity.

Introduction. Improving the energy efficiency of buildings is a global trend aimed at preserving the environment and reducing energy consumption. It is known that energy efficiency is one of the hallmarks of a highly developed society. In Ukraine, energy conservation is a top-priority strategic mission, the most important national problem and basic principle of the economy. Due to high prices for energy resources and a significant increase in requirements for the minimum permissible value of thermal resistance of building envelopes, autoclaved aerated concrete becomes the main effective wall material.
\end{abstract}


Analysis of recent researches and publications. In Ukraine, the requirements for the minimum permissible value of the thermal resistance of the building envelope have been significantly increased. According to the current standards for the design of thermal insulation of buildings [1], Ukraine is divided into two temperature zones and for them the minimum permissible values of the thermal resistance of the walls of residential and public buildings are approved. $R_{\mathrm{qmin}}, \mathrm{m}^{2} \cdot \mathrm{K} / \mathrm{W}$. For the first temperature zone (most territories - 19 regions of Ukraine) $R_{q \min }=3.3 \mathrm{~m}^{2} \cdot \mathrm{K} / \mathrm{W}$, for the second temperature zone ( 6 regions of Ukraine) $\mathrm{R}_{\mathrm{qmin}}=2.8 \mathrm{~m}^{2} \cdot \mathrm{K} / \mathrm{W}$. For comparison, all buildings built before the $80 \mathrm{~s}$ have a thermal resistance coefficient of $\mathrm{R}_{\mathrm{qmin}}=0.9 \mathrm{~m}^{2} \cdot \mathrm{K} / \mathrm{W}$.

The increase in thermo-technical requirements for enclosure structure required the use of energy efficient building materials, which combine: the required strength, uniformity and high thermotechnical properties [1]. Autoclaved aerated concrete becomes such material for external walls [2].

Modern technologies for the production of autoclaved aerated concrete make it possible to control its properties to achieve certain indicators. In practice, autoclaved aerated concrete has become the most demanded wall material in Ukraine. The growing popularity of autoclaved aerated concrete is due to four main factors: firstly, high environmental friendliness; secondly, the relatively low price; thirdly, working with it is the least laborious; fourthly, high energy efficiency, for example, D300-D500 aerated concrete masonry has the lowest thermal conductivity among homogeneous wall structures [3].

The aim and the tasks. Improving the energy efficiency of buildings through the use of environmentally friendly and energy-efficient wall material - autoclaved aerated concrete, which comply with the requirements for thermal resistance of enclosures structures.

Generalization of the results of modern local and foreign researches on the optimization of external walls made of autoclaved aerated concrete.

Improving the thermal protection of enclosures structures and their implementation should take place with careful preparation of design solutions and accompanied by experimental construction.

Materials and methods of researches. The object of researches is energy efficient wall material - autoclaved aerated concrete and aerated concrete products. The necessity of further improving the quality of raw materials of autoclaved aerated concrete and optimization of walls made of autoclaved aerated concrete are shown.

Research methods - generalization of the results of new foreign and local researches on the creation of high-quality autoclaved aerated concrete and effective products from it.

Results of the researches. Aerated concrete is one of the most environmentally friendly materials. In terms of radioactivity, aerated concrete belongs to the first conditional group, with the reduced radiation $\mathrm{A}_{\text {eff }}<54 \mathrm{~Bq} / \mathrm{kg}$ of becquerels per kilogram/mass

For example, heavy concrete and expanded clay concrete is corresponded to the second class $\left(\mathrm{A}_{\text {eff }}=54 / 120 \mathrm{~Bq} / \mathrm{kg}\right)$, ceramic bricks to the third class $\left(\mathrm{A}_{\mathrm{eff}}=125 / 153 \mathrm{~Bq} / \mathrm{kg}\right)$. The group of materials with high radioactivity - from 153 to $370 \mathrm{~Bq} / \mathrm{kg}$ (fourth class) - includes expanded clay and ceramic tiles.

Accommodation in houses made of aerated concrete comfortably. Autoclaved aerated concrete is non-combustible and fire-resistant, capable of withstanding at least 4 hours of unilateral exposure to fire without the appearance of signs of limiting states. Aerated concrete has a high fire resistance: REI 240.

An additional positive factor in favor of the predominant use of aerated concrete is its light weight. The use of aerated concrete products in the construction of buildings reduces the load on bases and foundations, which helps to reduce the total cost of construction.

Aerated concrete blocks are 2-3 times lighter than traditional wall materials such as bricks and ceramic blocks. Aerated concrete in the structures of external walls, with the development of the frame method of construction of civil, primarily residential buildings, has become the dominant material that makes it possible to create their architectural expressiveness, high consumer qualities of premises and the competitiveness of buildings in comparison with traditional solutions.

Considering that $15 \%$ to $40 \%$ of heat loss occurs through the walls, enclosures structures with high thermal resistance should be used.

Bulletin of Odessa State Academy of Civil Engineering and Architecture, 2020, no. 80, page 59-67 
The best option is to erect single-layer walls made of autoclaved aerated concrete. Aerated concrete is the only material, single-layer external walls of which fully provide normalized thermal resistance. For example, only one layer of aerated concrete with a density of D400 and a width of $40 \mathrm{~cm}$ is capable of providing the current standard of thermal resistance of walls at the level $3.3 \mathrm{~m}^{2} \cdot \mathrm{K} / \mathrm{W}$.

Aerated concrete in the European market of wall materials is not new, already well-approved. Ukraine also had experience of working with autoclaved aerated concrete, the production of which has begun in the 70s of the last century. Currently, the rebirth of aerated concrete is taking place, but it has already acquired qualitatively new characteristics, which have brought it to the leaders of the wall materials market.

The demand for autoclaved aerated concrete is consistently high, displacing traditional wall materials from the market. A number of modern plants for the production of wall products from autoclaved aerated concrete have been built in Ukraine, among them the UDK Gazobeton plant. UDK Gazobeton production is highly automated, which makes it possible to produce wall blocks with ideal geometric dimensions (measurement error $\pm 1 \mathrm{~mm}$ ) according to European standards. These blocks are recommended for thin-seam masonry with mineral glue with an average thickness of 2-3mm masonry joint. The laying of such blocks does not require leveling layers, and the thin seam of the masonry performs only a fastening, «gluing» function. This makes the wall uniform and prevents the formation of cold bridges, which occurs when laying on a standard cement-sand mortar.

During the laying of products with a high accuracy of geometric dimensions, bending stresses in the stones are reduced, which leads to a much later formation and development of cracks and to an increase in the overall strength of the masonry in compression.

The results of the research work of checking the dependence of the masonry strength made of aerated concrete blocks on the execution of the masonry joint are shown in Table 1. Within the framework of the experiment, 5 series of fragments of masonry, made from aerated concrete blocks of the same batch, but with a different design of the masonry joint, were tested.

Table 1 - Temporary resistance to compression of masonry, depending on the type of masonry joint

\begin{tabular}{|c|l|c|}
\hline № & Name of the masonry joint & Relative strength, \% \\
\hline 1 & Cement-sand mixtures, 10MM & 100 \\
\hline 2 & Thin-walled mortar, 2mm & 132 \\
\hline 3 & Thin-walled mortar with block grinding 1.5mm & 126 \\
\hline 4 & Polyurethane adhesive & 118 \\
\hline 5 & Dry surface & 121 \\
\hline
\end{tabular}

The results of the experiment lead to the following conclusions:

1. Masonry with a thin joint is 20-30\% stronger than masonry with a joint of standard thickness.

2. In masonry with a thin joint, the consumption of masonry mortar is 5-6 times reduced, which leads to a decrease in labor costs for masonry.

3. Due to a thinner layer of 1.5-2 mm adhesive mortar of blocks in accordance with Table 1, the possibility of the formation of «cold bridges» in the masonry of the outer walls from aerated concrete blocks is excluded.

In consequence of the possibility of manufacturing aerated concrete blocks with high accuracy of geometric dimensions, all the listed advantages of wall masonry are obtained.

Currently in Ukraine, most manufacturers produce high-precision products from autoclaved aerated concrete according to European standards.

Humidity has a significant effect on the heat-shielding properties of aerated concrete. The thermal conductivity of aerated concrete increases sharply with an increase in humidity, due to the fact that the thermal conductivity of water is 20 times higher than the thermal conductivity of air displaced from the pores of the material. The moisture content of external enclosures structures made of aerated concrete depends on the release moisture and operating conditions. The release moisture is one of the most important characteristics of the construction and operational properties of aerated concrete, which is subjected to mandatory control. 
According to the data of numerous studies, it has been established that in a limited range of humidity variation, the relationship $\lambda=\mathrm{f}(\mathrm{w})$ can be approximated by linear dependences. In Fig. 1 and in Table 2, the dependences of thermal conductivity at the sorption moisture content of aerated concrete $\mathrm{W}_{\mathrm{A}}=8$ and $\mathrm{W}_{\mathrm{b}}=12 \%$ are presented. To determine the increase in thermal conductivity of aerated concrete in a wet state compared to a dry one, use the formula:

$$
\Delta \lambda=\left(\left(\lambda_{\mathrm{B}}-\lambda_{\mathrm{c}}\right) / \lambda_{\mathrm{c}}\right) \cdot 100 \%
$$

where, $\lambda_{c}-$ the thermal conductivity in the dry state;

$\lambda_{\mathrm{B}}$ - thermal conductivity at operating conditions;

$\Delta \lambda$ - deviation of the coefficient of thermal conductivity in a wet state.

The value of $\Delta \lambda$ characterizes the increase in the coefficient of thermal conductivity in percent in a wet state compared to the thermal conductivity of aerated concrete in a dry state. The conducted experiments have established that the release moisture content of aerated concrete blocks significantly exceeds the sorption moisture content of aerated concrete, under operating conditions $\mathrm{A}: \mathrm{W}=8 \%$, and $\mathrm{B}: \mathrm{W}=12 \%$.

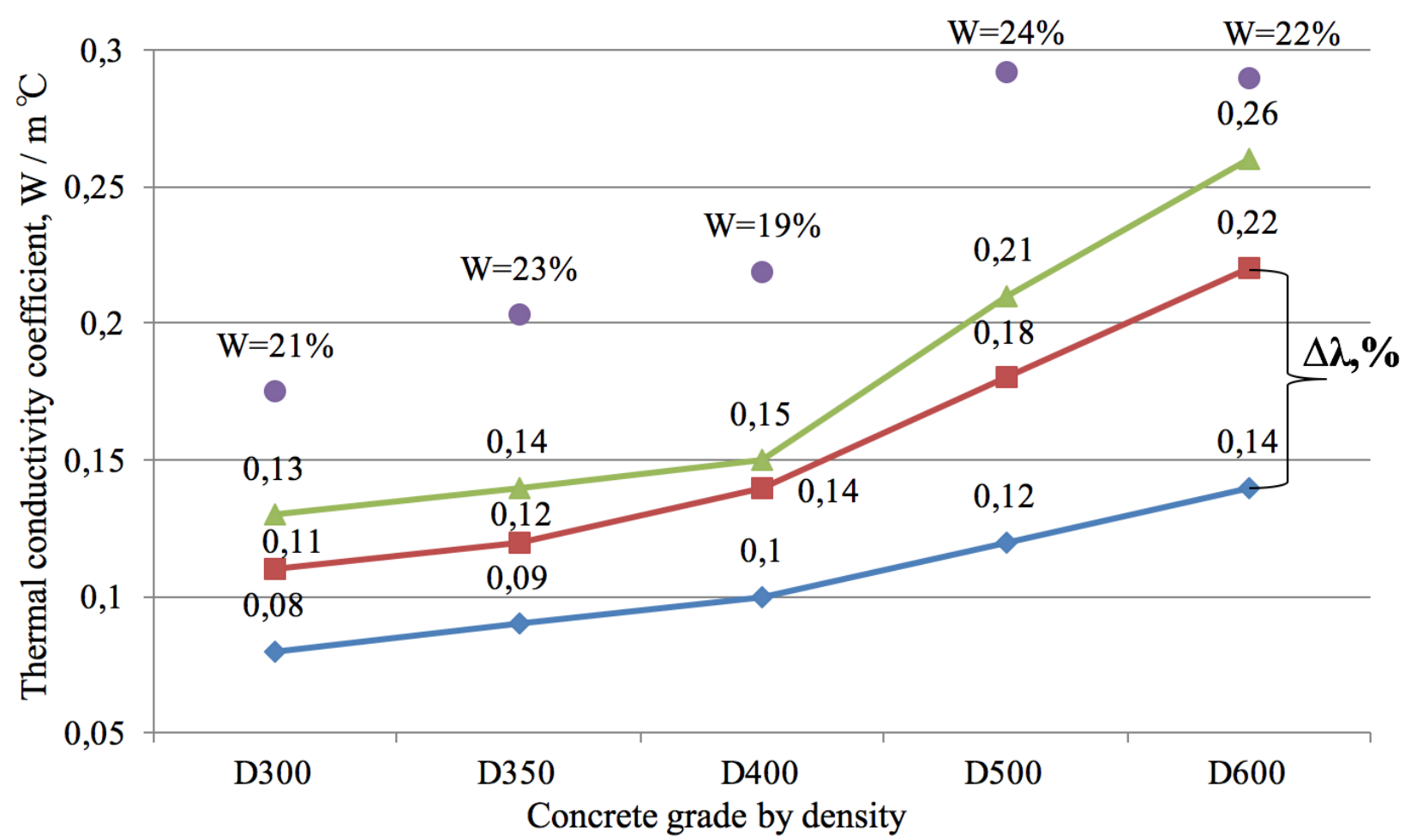

Fig 1. Basic thermotechnical properties of aerated concrete on sand according to the standard and experimental data:

The value of the coefficient of thermal conductivity in a dry state
Thermal conductivity coefficient for conditional operation A $(\mathrm{W}=8 \%)$
The value of experimental data on thermal conductivity in a wet state

In technical conditions for wall blocks made of aerated concrete, the grades of aerated concrete for density and thermal conductivity in a dry state are given in [4]. At the same time, the release moisture content of aerated concrete for grades D300-D400 is no more than 35\%, for aerated concrete D-500 and higher up to $25 \%$. In the standards for building heat engineering the values of the thermal conductivity coefficients of aerated concrete for the corresponding density and thermal conductivity in a dry state, also in a wet state for operating conditions $\langle\mathrm{A} »,(\mathrm{~W}=8 \%)$ and $\langle\mathrm{B}\rangle(\mathrm{W}=12 \%)$ are given. Table 2 [4] shows the deviations $\Delta \lambda, \%$ - coefficients of thermal conductivity in a wet state from the thermal conductivity of aerated concrete in a dry state. Analysis of the deviation $\Delta \lambda, \%$ for operating conditions «A» shows an excess of thermal conductivity in the wet state from $33.3 \%$ to $57.1 \%$, for 
operating conditions $\langle\mathrm{B}$ » the deviations are from $50.0 \%$ to $85.7 \%$ for aerated concrete grades D300D600. From the presented data on $\Delta \lambda, \%$ it can be seen that the thermal conductivity of aerated concrete in a wet state, with the indicated humidity indicators, is significantly, up to $85.7 \%$, higher than the thermal conductivity in a dry state. According to DSTU [4], the release moisture content of aerated concrete blocks should not exceed $23-35 \%$, which further increases the values of the thermal conductivity coefficients of concrete at such moisture content.

Table 2 [4] - Thermal performance of aerated concrete on sand according to the standard

\begin{tabular}{|c|c|c|c|c|c|c|c|}
\hline \multirow{2}{*}{$\begin{array}{l}\text { Concrete } \\
\text { grade by } \\
\text { density in a } \\
\text { dry state }\end{array}$} & \multirow{2}{*}{$\begin{array}{l}\text { The thermal } \\
\text { conductivity in } \\
\text { the dry state } \lambda_{\mathrm{c}} \text {, } \\
\mathrm{W} /\left(\mathrm{m} \cdot{ }^{\circ} \mathrm{C}\right)\end{array}$} & \multicolumn{2}{|c|}{$\begin{array}{l}\text { Humidity in } \\
\text { operation, \% }\end{array}$} & \multicolumn{2}{|c|}{$\begin{array}{l}\text { Thermal conductivity at } \\
\text { operating conditions } \lambda_{\mathrm{B}} \text {, } \\
\mathrm{W} /\left(\mathrm{m} \cdot{ }^{\circ} \mathrm{C}\right)\end{array}$} & \multicolumn{2}{|c|}{$\begin{array}{l}\text { Deviation of the coefficient } \\
\text { of thermal conductivity in a } \\
\text { wet state } \Delta \lambda, \%\end{array}$} \\
\hline & & A & Б & A & Б & A & Б \\
\hline D300 & 0.08 & 8 & 12 & 0.11 & 0.13 & 37.5 & 62.5 \\
\hline D350 & 0.09 & 8 & 12 & 0.12 & 0.14 & 33.3 & 55.6 \\
\hline D400 & 0.1 & 8 & 12 & 0.14 & 0.15 & 40.0 & 50.0 \\
\hline D500 & 0.12 & 8 & 12 & 0.18 & 0.21 & 50.0 & 75.0 \\
\hline D600 & 0.14 & 8 & 12 & 0.22 & 0.26 & 57.1 & 85.7 \\
\hline
\end{tabular}

In the Scientific Research Testing Laboratory of the OSACEA certified by the State Standard of Ukraine, experiments were carried out to determine the thermal conductivity coefficients of aerated concrete in dry and wet conditions. Analysis of the experimental results from Table 3 showed that in the range of aerated concrete density in a dry state from $317 \mathrm{~kg} / \mathrm{m}^{3}$ to $511 \mathrm{~kg} / \mathrm{m}^{3}$ and humidity from $19 \%$ to $24 \%$, the deviation $\Delta \lambda, \%$ is from $94.1 \%$ to $147.5 \%$. Consequently, the increase in the coefficient of thermal conductivity in the wet state increases by 1.5-2 times. According to the instructions of the standard [4], the release moisture is $25-35 \%$, which exceeds the values of moisture content and thermal conductivity coefficients in Table 3.

Table 3 - Experimental results for determining the thermal conductivity of aerated concrete in dry and wet conditions

\begin{tabular}{|c|c|c|c|c|}
\hline $\begin{array}{c}\text { Density of } \\
\text { concrete in } \\
\text { dry condition, } \\
\mathrm{kg} / \mathrm{m}^{3}\end{array}$ & $\begin{array}{c}\text { Thermal conductivity } \\
\text { in the dry state } \lambda_{\mathrm{c}}, \\
\mathrm{W} /\left(\mathrm{m} \cdot{ }^{\circ} \mathrm{C}\right)\end{array}$ & $\begin{array}{c}\text { Humidity, } \\
\%\end{array}$ & $\begin{array}{c}\text { Thermal conductivity } \\
\text { in the wet state } \lambda_{\mathrm{B}}, \\
\mathrm{W} /\left(\mathrm{m} \cdot{ }^{\circ} \mathrm{C}\right)\end{array}$ & $\begin{array}{c}\text { Deviation of the } \\
\text { coefficient of thermal } \\
\text { conductivity in a wet } \\
\text { state } \Delta \lambda, \%\end{array}$ \\
\hline 317 & 0.085 & 21 & 0.175 & 94.1 \\
\hline 351 & 0.093 & 23 & 0.203 & 118.2 \\
\hline 388 & 0.107 & 19 & 0.219 & 104.6 \\
\hline 475 & 0.113 & 24 & 0.292 & 147.5 \\
\hline 511 & 0.123 & 22 & 0.290 & 135.7 \\
\hline
\end{tabular}

To calculate the thermal resistance of external walls made of cellular concrete blocks in the initial period of operation of buildings, it is necessary to take into account the real values of humidity [5].

As the analysis of the thermal conductivity of aerated concrete in a wet state has shown, during the determination of the thermal resistance of external walls made of aerated concrete, it is necessary to take into account the actual values of humidity and the corresponding thermal conductivity, which will directly affect the thickness of the external fences or require additional insulation. 
Abroad, using specific examples of drawing up heat engineering passports of buildings, it was found that in the structure of total heat losses, more than $49 \%$ falls on ventilation, about $24 \%$ on windows and only $20 \%$ on walls. In this case, the dependence of the heat flux through the enclosure structure on its resistance to heat transfer has the form of a hyperbola, that is, with an increase in the resistance to heat transfer, heat loss through the structure decreases more and more slowly, and the costs of building the structure increase and at some point cease to be compensated by a decrease in heat loss. At the same time, the use of materials with different service life in the structure leads to the need for scheduled repairs with the replacement of less durable materials [6].

Consequently, the pursuit of energy conservation doesn't always lead to increased energy efficiency. A rational and economically feasible way to increase energy efficiency is a consumer approach to assessing the level of thermal protection and the active use of modern engineering energy-saving methods and technologies based on reasonable standards for energy consumption.

Modern structural and thermal insulation materials can be used for the construction of singlelayer enclosing structures, which are a priori more durable than multi-layer [7] when choosing a consumer approach to assessing the level of thermal protection.

Autoclaved aerated concrete, which fully complies with the required parameters of energy efficiency, has become such a main, strategic wall material.

Currently, in European countries and in Ukraine, the approach to the use of autoclaved aerated concrete products is changing - from small-piece to large-sized.

Analysis of the products of the leading manufacturers of autoclaved aerated concrete in Europe shows that the main emphasis in the nomenclature is placed on the production of large wall blocks (per floor), large-format wall panels (per floor and even 2 floors), floor slabs and coatings up to $7.2 \mathrm{~m}$ long. The use of large-format enclosure structures reduces the number of seams and increases the thermal properties of the building, provides a favorable indoor climate and promotes high-speed construction. In developed foreign countries and in Ukraine, high-speed construction, energy efficiency, environmental friendliness are the current main trends in the development of multi-story frame-monolithic housing construction. Ukraine has been and remains a promising country for the development of production and consumption of autoclaved aerated concrete. In Russia, the introduction of energy-saving technologies in construction began in 1995, when the required values of the reduced resistance to heat transfer of enclosure structures is escalated. Considerable experience has been accumulated.

Having shared his views on some aspects of energy saving in the article [8] Vladimir Gagarin, Doctor of Technical Sciences, Professor, Head of the Laboratory of Building Thermal Physics in Research Institute of Building Physics of the Russian Academy of Architecture and Building Sciences (Moscow), one of the leaders of the scientific school of building thermal physics in the field of the theory of heat and mass transfer in building materials and enclosure constructions:

- in the conditions of the expected energy deficit, any significant energy savings will be relevant if its implementation isn't accompanied by the opposite effect, that is, it won't be energyintensive. To do this, all specific energy saving measures must be economically viable. Another important condition for the application of energy-saving measures shouldn't reduce the durability of construction objects, otherwise they also turn into energy-consuming ones;

- increasing requirements for thermal protection of buildings leads not only to an increase in the cost of construction, but also negatively affects the durability of the enclosure structures;

- increasing the thermal protection of walls won't be able to lead to significant savings in energy consumption in the country, but is associated with significant difficulties and costs in the construction and operation of buildings;

- an activity that does not pay off economically is, in essence, energy-consuming and not energy-saving;

Bulletin of Odessa State Academy of Civil Engineering and Architecture, 2020, no. 80, page 59-67 
- as shown by the simplest calculations, a further increase in the standardized thermal protection of enclosure structures isn't economically feasible (there is no payback);

- rationing of increased thermal protection of walls should be widely and comprehensively discussed and economically justified. The introduction of enclosure structures with increased thermal protection should take place with a careful study of design solutions and be accompanied by experimental construction.

\section{Conclusions:}

1. The main, strategic wall material in Ukraine has become autoclaved aerated concrete, which fits perfectly into the global trend in the development of energy efficient construction.

2. Aerated concrete is the only material, single-layer external walls of which fully provide normalized thermal resistance.

3. In Ukraine, small wall blocks from autoclaved aerated concrete are mainly produced with high accuracy of geometric dimensions, which make it possible to perform thin-joint masonry.

4. It is necessary to expand the range of products manufactured from autoclaved aerated concrete by including reinforced and large-format products (large-sized wall blocks and panels, floor slabs and coatings).

5. During the determination of the thermal resistance of external walls made of aerated concrete in a wet state, the thickness of the external walls must be adjusted in accordance with the actual values of humidity and thermal conductivity of aerated concrete in order to ensure the normalized thermal resistance of the external walls.

\section{References}

[1] V. Martynov, E. Martynov, I. Krylov, A. Herega, "Influence of the structure of a material solid phase on the properties of cellular concrete", International Journal of Composite Materials, vol. 5, no. 4, pp. 79-80, 2015. doi: 10.5923 / j.cmaterials.20150504.02.

[2] R. Cabrillac, B. Fiorio, A. Beaucour, H. Dumontet, S. Ortola, "Experimental study of the mechanical anisotropy of aerated concretes and of the adjustment parameters of the introduced porosity", Construction and Building Materials, vol. 20, no. 5, pp. 286-295, 2006.

[3] M. Collepardi, "Innovative Concrete for Civil Enginneering Structures: SCC, HPC and RPC", Workshop on new Technologies and Materials in Civil Enginneering, Milan, pp. 1-8, 2003.

[4] DSTU B V.2.7-137:2008. Bloky z nizdryuvatoho betonu. Stinovi dribni. Tekhnichni umovy. Kyyiv: Ministerstvo rehional'noho rozvytku ta budivnytstva Ukrayiny, 2008.

[5] DBN V.2.6-31:2016. Teplova izolyatsiya budivel'. Kyyiv. Ministerstvo rehional'noho rozvytku budivnytstva ta zhytlovo-komunal'noho hospodarstva Ukrayiny, 2017.

[6] B.V. Shevelev, N.M, Fialko, L.F. Chernykh, I.M. Sukhorosov, V.A. Doroshenko, A.I. Stupnik, V.I. Savenko, "Issledovaniye, razrabotka i vnedreniye effektivnykh energosberegayushchikh konstruktsiy i tekhnologiy v stroitel'stve", Budivnytstvo Ukrayiny, no. 1, pp. 2-8, 2010.

[7] R.F. Runova, L.O. Sheinich, O.G. Gelevera, V.I. Gots, Osnovy vyrobnytstva stinovykh ta ozdoblyuval'nykh materialiv, Pidruchnik. TO, KNUBA, 2001.

[8] V.G. Gagarin, "Makroekonomicheskiye aspekty obosnovaniya energosberegayushchikh meropriyatiy pri povyshenii teplozashchity ograzhdayushchikh konstruktsiy zdaniy", Stroitelnye materialy, no. 3, pp. 8-16, 2010. 


\title{
ГАЗОБЕТОН ЯК ЕНЕРГОЕФЕКТИВНИЙ МАТЕРІАЛ ДЛЯ СТІН
}

\author{
1'Заволока М.В., к.т.н., професор, \\ mvzavoloka@ukr.net, ORCID: 0000-0002-2080-1230 \\ 1заволока Ю.М., інженер-технолог, \\ yurii.m.zavoloka@gmail.com, ORCID: 0000-0003-0033-6025 \\ ${ }^{1}$ Гриньова I.I., к.T.н., \\ irene.grinyova@gmail.com, ORCID: 0000-0001-7637-6029 \\ 1Заволока Ю.В., доцент, \\ yurii.zavoloka1@gmail.com, ORCID: 0000-0002-2741-0515 \\ ${ }^{1}$ Одесская державна академія будівниитва і архітектури \\ вул. Дідріхсона, 4, м.Одеса, 65029, Україна
}

\begin{abstract}
Анотація. В умовах посилення теплотехнічних вимог до огороджувальних конструкцій показані переваги енергоефективного стінового матеріалу - автоклавного газобетону і газобетонних виробів.

Узагальнено вітчизняні та зарубіжні дослідження в галузі раціонального використання автоклавного газобетону для зовнішніх стін у сучасному будівництві енергоефективних будівель та оптимізації конструктивних рішень газобетонних стін. Найважливішою теплофізичною характеристикою для оцінки теплового опору зовнішніх стін 3 газобетону $€$ значення коефіцієнта теплопровідності. Істотний вплив на теплопровідність надає вологість газобетону, відпускна вологість в рази перевищує розрахункову вологість передбачену стандартами по будівельній теплотехніці і умовам експлуатації. На початкових етапах будівництва вміст вологи в газобетоні перевищує вміст вологи, встановлену у нормативній документації умовами експлуатації, що вимагає перерахунку теплового опору стін будівель з урахуванням реальної вологості газобетону, що використовується під час будівництва. Дано докладне пояснення встановленої у вигляді гіперболи залежності теплового потоку через огороджуючу конструкцію від іiі опору теплопередачі і наведені залежності різниці теплопровідності від вологості блоків газобетону. При аналізі впливу вологості на теплопровідність газобетону була використана характеристика відхилення $\pm \Delta \lambda$ теплопровідності газобетону у вологому стані від теплопровідності бетону в сухому стані. За результатами проведеного в ОДАБА експерименту дані основні висновки i рекомендації щодо визначення коефіцієнта теплопровідності газобетону в сухому і вологому стані. Представлені деякі аспекти по проведеному енергозбереженню в практиці будівництва, за матеріалами підготовленими д.т.н., проф. Гагаріним В.Г. Показано необхідність вдосконалення конкретних енергозберігаючих заходів, які повинні економічно окупатися і не знижувати довговічність об'єктів будівництва. Дано узагальнені висновки і рекомендації.
\end{abstract}

Ключові слова: енергоефективність будівель, раціональне застосування, автоклавний газобетон, зовнішні стіни, оптимізація стін, аспекти, коефіцієнт теплопровідності, вологість. 


\title{
ГАЗОБЕТОН КАК ЭНЕРГОЭФФЕКТИВНЫЙ МАТЕРИАЛ ДЛЯ СТЕН
}

\author{
${ }^{1}$ М.В. Заволока, к.т.н., профессор, \\ mvzavoloka@ukr.net, ORCID: 0000-0002-2080-1230 \\ ${ }^{1}$ Ю.М. Заволока, инженер-технолог, \\ yurii.m.zavoloka@gmail.com, ORCID: 0000-0003-0033-6025 \\ ${ }_{1}^{1}$ И.И. Гринева, к.т.н., \\ irene.grinyova@gmail.com, ORCID: 0000-0001-7637-6029 \\ ${ }^{1}$ Ю.В. Заволока, доцент, \\ yurii.zavoloka1@gmail.com, ORCID: 0000-0002-2741-0515 \\ ${ }^{1}$ Одесская государственная академия строительства и архитектуры \\ ул. Дидрихсона, 4, г. Одесса, 65029, Украина
}

Аннотация. В условиях ужесточения теплотехнических требований к ограждающим конструкциям показаны достоинства и преимущества энергоэффективного стенового материала - автоклавного газобетона и газобетонных изделий.

Обобщены отечественные и зарубежные исследования в области рационального применения для наружных стен автоклавного газобетона в современном строительстве энергоэффективных зданий и оптимизации конструктивных решений стен из газобетона. Важнейшей теплофизической характеристикой для оценки термического сопротивления наружных стен из газобетона является значение коэффициента теплопроводности. Существенное влияние на теплопроводность оказывает влажность газобетона, отпускная влажность в разы превышает расчетную влажность предусмотренную стандартами по строительной теплотехнике и условиям эксплуатации. В начальные этапы строительства влажность ячеистых бетонов превышает влажность установленную в нормативной документации условиями эксплуатации, что требует пересчета термического сопротивления стен зданий с учетом реальной влажности газобетона используемого при строительстве. Дано подробное объяснение установленной в виде гиперболы зависимости теплового потока через ограждающую конструкцию от ее сопротивления теплопередаче и приведены зависимости разности теплопроводности от влажности блоков газобетона. При анализе влияния влажности на теплопроводность газобетона была использована характеристика отклонения $\pm \Delta \lambda$ теплопроводности газобетона во влажном состоянии от теплопроводности бетона в сухом состоянии. По результатам проведенного в ОГАСА эксперимента даны основные выводы и рекомендации по определению коэффициента теплопроводности газобетона в сухом и влажном состоянии. Представлены некоторые аспекты по проведенному энергосбережению в практике строительства, по материалам подготовленным д.т.н., проф. Гагариным В.Г. Показана необходимость совершенствования конкретных энергосберегающих мероприятий, которые должны быть экономически окупаемыми и не снижать долговечность объектов строительства. Даны обобщенные выводы и рекомендации.

Ключевые слова: энергоэффективность зданий, рациональное применение, автоклавный газобетон, наружные стены, оптимизация стен, аспекты, коэффициент теплопроводности, влажность.

Стаття надійшла до редакції 30.07.2020 